\title{
Illustration of Gender Stereotypes in the Initial Stages of Teacher Training
}

\author{
Pilar Aristizabal Llorente ${ }^{1, *}, M^{a}$ Teresa Vizcarra Morales ${ }^{2}$ \\ ${ }^{1}$ Departamento de Didáctica y Organización Escolar, Escuela Universitaria de Formación del Profesorado, Euskal Herriko Unibertsitatea \\ (UPV/EHU), Vitoria-Gasteiz, 01006, Spain \\ ${ }^{2}$ Departamento de Didáctica de la Expresión Plástica, Musical y Corporal, Escuela Universitaria de Formación del Profesorado, Euskal \\ Herriko Unibertsitatea (UPV/EHU), Vitoria-Gasteiz, 01006, Spain
}

\begin{abstract}
In this article we present a study carried out over the period 2009-2010 in the Vitoria Teaching Institute, part of the Basque Country University (Escuela Universitaria de Magisterio de Vitoria de la Universidad del País Vasco [UPV/EHU] ) in which we attempt both to identify the perceptions of the student body surrounding the issue of gender equality and their perceived need to be aware of said issues during the initial stage of their teacher train ing. In brief, we will look at the underlying gender stereotypes found within the student body at the initial stages of training. We track a trajectory which attempts to define different stereotypes and the way in which people are socialised within these stereotypes; as well as looking at the role the school plays in said socialisation. We provide a case study, the key strategy of which has been to use discussion groups as the way of obtaining information.
\end{abstract}

Keywords Initial Stage of Teacher Training, Learning in the Work-Place, School-Students Relationship, Gender Stereotypes

\section{Introduction}

Twenty years have passed since the linking of in fant and primary education into the single school. Upon planning this study, we aimed to know and comprehend the underlying perceptions and ideas surrounding the issues of gender equality in students in the third year of teacher training; as well as to reflect upon the necessity of being conscious of said issues in the initial stages of training. We wished to focus our investigation on the following questions: have we overcome gender stereotypes or, on the contrary, do we continue to propagate the same sexist frameworks? Which are the expected behaviours from young girls and boys by our students? Are there mistaken beliefs which arise from the stereotypes? How are relations of equality understoof? Briefly, we wished to bring to the surface the opinions and attitudes among our student body, with the aim to allow for future proposals for the improvement of teacher training in regard to issues of gender.

\section{Theoretical Framework}

In order to reflect upon gender stereotypes, we must know

* Corresponding author:

p.aristizabal@ehu.es (Pilar Aristizabal Llorente)

Published online at http:/journal.sapub.org/edu

Copyright (C) 2012 Scientific \& Academic Publishing. All Rights Reserved what the latter are and how they influence the construction of gender identity - whether masculine or feminine. For ([17]: 113-137), stereotypes constitute the "sum of shared beliefs regarding personal characteristics, usually personality traits, but also certain behaviours, associated with a group of people". According to[15] and[12], one of the key characteristics of stereotyping is that it determines a certain viewpoint regarding different aspects of reality. Said viewpoints are accepted without questioning and operate in an unconscious manner influencing our thinking, talking, feeling and living mechanisms. That is to say, they condition our rationality, our emotivity and our behaviour. A mong the different stereotypes which our thinking can generate, there are sexist stereotypes, those which define wo man assuming certain determined roles in her relation to man, and vice versa.[10]. Gender stereotypes are "the sum of thinking processes surrounding personality and behavioural traits of wo men and men, based on the acceptance of the patriarchal cultural model and the relation of superiority of one and the dependency of the other.' ([15]: 116-136).

In due thanks to femin ist studies and investigation, in present day we know much more than we used to regarding the way in which young boys and girls acquire gender roles during the process of socialisation, since the former have exposed that one learns to "be a boy" or "be a girl". In this manner we appropriate thought and behavioural models which are considered acceptable in out society[6]. Said models are different depending on factors of class, and national and local culture. According to [13], everything is 
predisposed in society so that each role can be assumed in a manner which may appear natural, as though the roles were consequence of existing physical differences rather than human intervention. In the process of socialisation, the school, family and media appear as the three large institutions which influence individual identity and the social classification of persons in accordance with sex-converting the biological difference into a social difference. The symbolic representation of what it is, and what it must be, to be a man or a woman, conditions the immersion of each pers on within society[12] acting within the schoolas a tool to disseminate and propagate gender roles as assigned with patriarchal society by way of different mechanisms. In patriarchal societies, young boys are encouraged to be active, and to develop their own personal judgement and autonomy. On the other hand, young girls are forced to develop mechanisms which construct a dependent personality, without autonomy and always in service to others. This situation has provoked a partial development of persons, since wo men acquire abilities, values and attitudes' related to the private sphere, and men develop those related with the public realm. Consequently, young ladies often do not view themselves as active protagonists of the surroundings they inhabit.

For this reason, it is necessary to know the expectations of future educational training as regards expected behaviour from young girls and boys, in order to reflect upon how these influence expectations in the propagation of stereotypes, since, as affirmed by[12], since are born, the image which is projected upon each pers on conditions his or her adult life. In our society, masculine stereotypes are bound to professional activity and the public realm, attributing certain traits to men such as, activity, aggressiveness, authority, bravery, a commanding stance and an aptitude for the sciences. Furthermore, it is widely affirmed that men are more violent than woman, that they are greater risk-takers, that they repress their feelings, that they speak less about intimate issues, etc. Traits associated with women are activities of care, jealous of privacy and lacking control over power, attributing qualities to them such as passivity, tenderness, submission, obedience, docility, shyness, lack of in itiative, tendency to dream, doubt, emotional instability, lack of control, dependency, an aptitude for literature and weakness. In the same manner, it is accepted that women are more intuitive, more fearful and more likely to put in effort[12]; [14]. Femin ine roles have always been as sociated with grace and beauty, delivery and devotion, children's education, fragility and sweetness...[10].

According to[13], teaching operates in a manner where different boys and girls are formed by way of continuous correction of those behaviours which surpass gender norms.[8] collects from different empirical investigations (i.e. from Subirats and Brullet, 1988; Freixás and Fuentes, 1986; Spender, 1982, Stanworth ,1981; Warrington and Younger, 2000 and Francis, 2000), which, in the classroom, girls are spoken to less, they are required to participate less, they are used as examples less, and, in general, they are stimulated less. Similarly, the afore-mentioned research constates that girls dispose of a lesser space for play, their games are less valued and less attention is paid to their explanations regarding their activities out of school. At the same time, often they are asked to take charge of the boys, to pay them attention or to help them with an activity. According to[3], the differences between feminine and masculine communication styles begin at very early stages, at two years of age already girls are solicited for help more often than boys (which is a way of recognising one's own inability); and at four years of age, in mixed groups, already the boys do not talk, they make comments which distract or perturb and they affirm thems elves emphatically. This means that girls and boys learn at a very early stage the patterns of tone, articulation and intonation which "correspond" to those of their gender. Girls and boys are given different physical abilities, but these qualities are complementary and are coupled: control-strength, softness-effectiveness, prudence audacity, and the difference appears as something natural, without this being necessarily the case at all times. According to Beer (2005, in[16]), "the pattern used to measure girls is the model used for boys. The achievement and mode of functioning of the boys is that which establishes the measure for comparison. In light of that measure, the girls tend to be at an inferior level, since it is usual to male sporting achievement and activity as the unit to measure all other activity by". Boys and girls interiorise these expectations from teachers, where the obtained result could be the consequence of their own personal effort or of the positive or negative consideration of the teacher. Teachers, in general, place higher hopes on students which demonstrate different attitudes in reference to boys and girls, and that, obviously, influences its results. According to certain studies, boys who do well at school are the "favourites" among teachers, more so than girls wh ich obtain brilliant results. Conversely, girls who are not good students are in a better position than boys, even those which obtain results equally bad to the boys[10].

In this process of socialis ation, the school constitutes on of the socialising elements which configures the personality of persons, as well as their manner of feeling and thinking. It is not the only nor the first institution to do, but it asserts huge influence due to the long time which boys and girls spend within her and the special position attributed by society to the school realm. The contents and values passed on in the educational process are of great importance since they influence young persons reinforcing the received culture in the familiar surrounding and supporting - or removing security and self-esteem[4]. We know that the school does not create the differences between persons of different sex, but it does help to legitimise them. The school is a clear reflection of the society in which we move and in which our students are educated. It has operated within an androcentric model of society which has reproduced itself through the so-called hidden curriculum, which has been propagated in the schooling system unless the teacher training places special emphasis on the questioning, by its students, of 
genderstereotypes ([12]:133). In the actual school, all formal differences related to a curriculum differentiated by sex have disappeared. Similarly, so have the existing differences in remain ing activities, since the same content is offered to boys and girls, but the hidden and, generally, unconscious differences are maintained in all educational systems and they are passed on from the very first stages of school despite unintentionally - through the hidden curriculu m[10]. In this sense,[12] point out that the school can be a tool at the service of the reproduction of social relations; or an instrument to interrupt said re lations and form the bud of new relations which are not marked by inequality nor rein force social disadvantages. The transformational possibility which the school holds lies in visualising that which is presented as impossible in the curriculum. Special attention would have to be paid to the educational contents which are transmitted via the school and the processes of social relating which are developed there. In order to realise a critical revision of sexist stereotypes found in school content it is necessary to analyse the models which are passed on in the school via the images, content and language of school text-books[12]. Sexism exists in text books, in those instances where images and allusions to women and men are unequal, when the symbolic representation of the feminine is discriminated against by its scarce appearance in the different text books, when images and contents harbour sexist stereotypes, and when women and wo man's world does not appear or appears in a distorted manner. In this sense, one of the "forgotten" contents in text-books is that of housework. Neither in history, nor science, nor technology books is it, for example, mentioned what types of ovens, kitchen, fridges, driers, or cleaning and ironing systems have been utilised in order to reach the current sophisticated systems. Let us bear in mind that, currently, young generations -both girls or boys-do not receive any formation surrounding those types of knowledge which, in a discriminatory manner, have traditionally been associated with women, and which form necessary knowledge for personal autonomy (Lomas, in[2]). What lies behind this is the co-educational school holding as its objective to eradicate gender stereotypes, overcoming social differences and hierarchies between boys and girls.

Faced with the choice of a professional career, stereotypes define which activities are appropriate for some and for others, and as such they will influence professional development[9]. In 2010 the European Commission presented the manner in which various European countries accommodate inequality between men and women within education. In this report it can be observed that differences between the sexes persist in subject choice as well as grades, and it indicates that traditional stereotypes continue to be the main obstacle for gender equality within education[7]. It is necessary to discover and demonstrate that, despite the fact that it may seem that the principles of equality are primary within schools and that we have norms and regulations enacted which seek educational equality; in reality, there are multip le hidden forms of discrimination and reproduction of stereotyped models. Due to this, it is necessary to understand preconceived, often false, ideas surrounding women ([12]:131).

\subsection{Method}

We are faced with a case study which attempts to reach the persons implicated in the investigation, in order to comprehend their reflections, motivations and interpretations of their content and in order to view rea lity through their eyes. Case studies facilitate the immersion of a determined content in order to perceive the difficulties and opportunities which present themselves during a process. The aim of this investigation is to analyse the case of the University of Vitoria teacher training and ask ourselves what occurs in said context, via its protagonists.

The strategies for data collection have fundamentally been a semi-open questionnaire and discussion groups carried out with students and teachers.

As regards the procedure followed in the investigation: in order to operate the told for data collection it was necessary to be aware of previous research surrounding this subject, and consequently the tools for investigation have been constructed based upon those used in previous research, adapted for our circumstances and our object of study. We used questionnaires in order to in itially approach the issue, and in order to guide the discussion groups. Following this we collected the questionnaire results and transcribed the recordings gathered in the discussion groups.

As regards analysis and data handling, a content analysis has been carried out through hierarchic hermeneutic categories, which have been codified and ordered with the help of software NVIVO 8. Lastly, a report was composed outlining the data gathered with the different instruments. This process has not been linear at all times, in some cases we have had to do so retrospectively.

Context and participants in the investigation: the investigation is carried out in the University of Vitoria teacher training, and the partic ipating persons are part of the latter. It is a small centre which offers certain advantages, since we all know each other and communication is thus easily enabled. The number of wo men and men in the faculty is fairly balanced: 42 men and 36 wo men, of which 4 men and 11 wo men partook in the discussion groups.

There are three specialisations in the Faculty, Infant Education, which is aimed at teachers which will develop their profession with girls and boys of 0-6 years; Primary Education, aimed for training teachers of girls and boys between 6 and 12 years of age, and Physical Education which aims to train teachers specialising in physical education for boys and girls of 6 to 12 years. Teaching degrees are much feminised, in that, for example, in the course matriculation 2009-2010, the percentage of women matriculating in Infant Education was $92 \%$ and in Primary Education $70 \%$. However in Physical Education, the data is inverted as we see a $68 \%$ male matriculation. In this investigation the participants of the third year for all three diplo mas take part. We were particularly interested in the collective opinion of male and female students about to 
fin ish their degree, since we wanted to know their opinion and their attitudes towards this issue, as well as the deficiencies which they detected in the degree. 217 questionnaires were collection and 18 discussion groups were carried out.

The triangulation of data: in order to quality-assure the research we used the triangulation method of informants, instruments and investigators, since we were contrasting the same circumstances from different viewpoints.

\subsection{Results}

As regards stereotypes, when asked what they see in the school, in the first instance in the majority of groups are of the opinion that there are no stereotypes present within our Faculty. However, we have been surprised to see how, in their responses, there appear various stereotypes which we have encountered in the scientific literature, some of which related to the physical and personality traits of men and wo men, as well as others, related with study or professional choices. When we asked them, via the questionnaire, if they could define stereotypes, in the majority of cases, they say that they know what they are and they could define the concept, as seen in Figure 1.

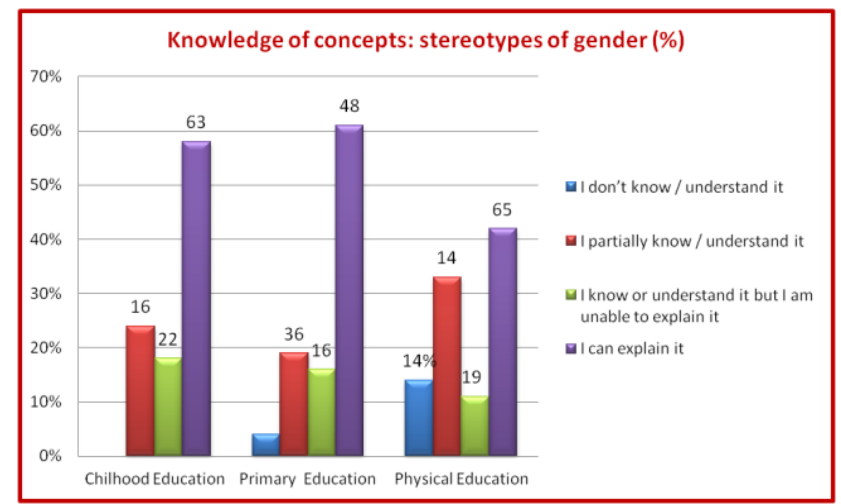

Figure 1. knowledge of oncepts by specialisation: gender stereotypes

On the other hand, within the discussion groups they affirm that there are no stereotypes, yet they say so demonstrating contradictions in their discourse. So, in the first instance, in the majority of groups they say that they do not see stereotypes, that there are none.

"I don't think that there are stereotypes in this school. We haven't seen stereotypes." (Girl/ Infant/GD14/ 2009/09/22)

Despite the fact that not all people participating see it the same way, they all point to the fact that in the teachertraining faculty of the University the issue of stereotypes has not sufficiently been addressed, nor do they self-criticise or analyse.

"The issue of stereotypes has not been touched upon in any manner, it has not been criticised nor utilised." (Gir//Primary/GD15/ 2009/09/23)

The student body believes that the presence of stereotypes, in our case, is important, and in this manner, in Figure 2, we can see to which extent they see them as present.

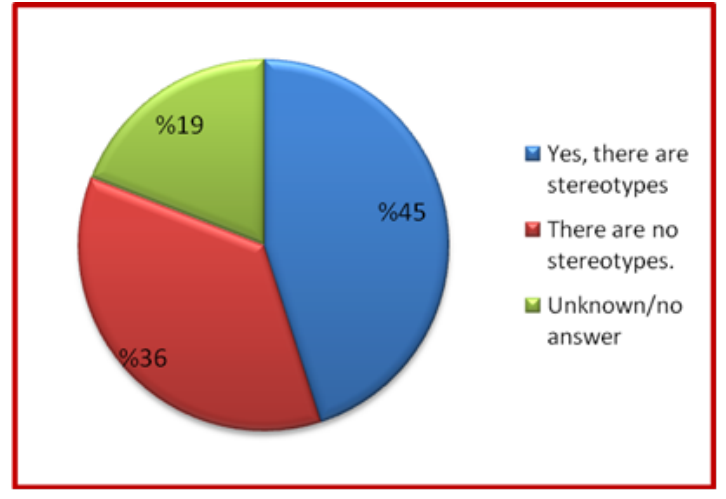

Figure 2. Presence of gender stereotypes in Teacher Training Faculty at the University

Different behavioural or physical traits are attributed to each sex due to stereotypes. Within the discussion groups, there appear stereotypes regarding behavioural differences between men and women, regarding personality traits, physical characteristics and capacity and also other differences related to choices regarding their professional future. A mong behavioural differences assigned to boys and girls there appear concepts such as class participation, leadership, team formation and use of space which are the fruit of socialisation experienced by boys and girls. As regards class participation they affirm that when the teacher asks a question, it is boys who answer and girls who rema in silent.

"At least within our class, boys participate more and girls are quieter. I think that in our class this is how it is." (Girl/ P.E. / GD1/ 2009/05/17)

"That is true, and also in the gym when it is time to do something, us boys get involved more, I don't know why this is the case, we are more enthusiastic about things. When it comes to sports, we're more competitive than the girls." (Boy/ P.E. /GD2/ 2009/05/17)

As regards leadership, whilst the majority commonly state that there are no leaders, there are some who are of the opinion that leadership is at the service of people, those who are less easily embarrassed assume the role of leaders. In any case they think that at this stage there are cliques which form but no group leaders.

"Leadership, I think, depends on the person, not on whether they are a boy or a girl. If a person is less self-conscious they will assume leadership more easily". (Girl/ In fant/GD3/ 2009/05/20)

When asked to elaborate, they state that differences in leadership are down to the fact that the girls hold a calmer disposition and are more self-conscious; whereas the boys are fearless and do not mind being uncouth, the girls are afraid of making mistakes and looking silly.

"When teachers ask a question it is boys who answer and girls who are quiet. Because we're more self-conscious, and we're scared of looking silly. I, for instance, often remain silent, because I think that I will say the wrong thing. The boys are not scared, they say what they want and at times it might be silly, but..." (Girl/ P.E. / GD1/ 2009/05/17) 
“....as regards class participation, boys get involved more, but not because we want attention, rather because we are more extroverted, or more insensitive, I don't quite know how to put it." (Boy/ P.E. / GD2/ 2009/05/17)

Within the theoretical framework we saw that, throughout the process of socialisation, girls are addressed less often than boys are within the classroom. The former are asked to participate less and generally stimulated less. As can be appreciated in the opinions gathered, the student body does not question whether the behaviours attributed to each sex are a result of socialisation, and this leads them to accept the patriarchal cultural model, without questioning. On the other hand, in all groups it is admitted that when it comes to group-work, girls pair off with girls and boys pair off with boys. They mention that, it is not due to the fact of being male or female, rather because they feel more comfortable that way, because they have more things in common, and this is something they have learnt throughout the process of socialisation in the school.

"...yes, however, the truth is, that when we have to couple up, the majority of times it's two girls or two boys. I don't know if it's because us girls are more open with each other so we gravitate towards each other when it comes to group work, or if it's something we've been conditioned into since very young, but it's true that at playtime, for example, we take part less than the boys". (Gir1/ P.E./GD18 / 2009/09/24)

"...and when we have to do practice work or a presentation, the groups tend to be boys or girls only, as in: we don't mix". (Boy/ P.E. / GD8/ 2009/09/21)

As regards stereotypes related to pers onality, that which is expected from each person, they self-attribute that boys are more competitive and much more easily angered. All the girls in the group agree with the following statement:

"Another stereotype is that (boys) are more competitive, but it's true, they are! I say it because that's what I see. I've played with many boys and they get very angry. But with girls the same does not occur." (Girl/Infant/GD4/2009/05/ 20).

On the same line of thinking, they refer to girls being smarter and more hard-working, as well as calmer...

"There are always the stereotypes that girls are smarter and more hard-working... You can see that in house-share advertisements, they're always seeking girls. People prefer girls". (Boy/ P.E. / GD9/ 2009/09/21)

You could say that the student body of the teacher training Faculty in the University of Vitoria abides by the social expectations surrounding gender and that they do not question the reasons behind them. As regards stereotypes related to physical characteristics and capacities, despite stating that they have not witnessed any gender stereotypes, when in a certain subject it is claimed that boys are stronger and faster, they say that it is not a stereotype, that "it is the case". They insist that women and men are physically different and they justify stereotypes based on differentiated biological characteristics:
"In Physical Education, when base physical aptitudes have to operate, the boys are always stronger, faster, but because this is the way it is". (Girl/ P.E./GD1/ 2009/05/17)

As we can see, they accept this statement, they do not question it, nor are they conscious of how embedded the stereotypes are, stating them as objective fact. As regards physical characteristics, they are of the opinion that there are some sports which are more "suited" to girls and others which are more adequate for boys. They state that in resistance sports there is a great difference between boys and girls and they admit that the cause lies in the physical characteristics of the girls. In the same way, it is clear to them that girls have more of an aptitude for following rhythm, and that boys are stronger and faster.

"But in resistance sports and others we have learnt that our (girls') lungs are s maller, there are physical differences. Depending on which sports... for example I play football, and I notice it a lot there. For example, in our team, when we play against boys, we don't play against our own age group or older, we play against junior teams and normally they win because, in the end, they're faster..." (Girl/ P.E./ GD1/ 2009/05/17)

"It's clear: there are sports which are easier for girls, and girls too, physiologically, find it easier to follow rhythm than boys do". (Boy/ P.E. / GD8/ 2009/09/21)

The opinions of the student body coincide with the results of the investigation carried out by Sheila Scraton. Stereotypes regarding girls coincided with the view that girls have lesser resistance, are weaker, more elegant and their movements are more precise. By way of these stereotypes there is a belief that certain activities are "better suited" for girls and, as a result, they are given less space in which to practice sport. Gracefulness, weakness, and lack of strength and resistance are associated with females. Focus and force of discourse are measured using the masculine model as reference, rather than considering the characteristics present in the sporting activity of women as a pattern with its own personality[16].

In the words of[5], society asks many things of the school, among said things it asks the school socialise the younger generations. To do so, the school has its own framework and at the base of said framework, are women. This is possibly because woman's work, both within and outside the home, has been related with the care of others. We cannot forget that it is women who have been allocated the task of schooling the very youngest, since teaching was viewed as an extension of mothering, and in this manner it offers us plenty of information through the course of history. Within education, traditional stereotypes continue to be one of the major obstacles to reach equality, they show deficiency in their formation:

"I think we are lacking a practical plan, because we are already aware of the theory, but we don't quite know how to put it into practice, how to put it in action with boys and girls." (Girl/ Infant/ GD1 1/ 2009/09/22) 
"I would like to know if psychometrically it is better to separate boys and girls and to know why this is or is not the case." (Girl/Infant/ GD 12/ 2009/09/22 12)

"It would not be that difficult to organise an event where we would mention four little things, to see if it is normal for all little girls to want to be princesses at some point, how to adapt songs or stories, in practice we do not do that which we learn at university and we then have to deal with the situation alone" (Girl/ Infant/ GD 12/ 2009/09/22)

They appear preoccupied with the is sue of how to prevent the boys from occupying the entirety of the playground space, leaving the girls with the space "left over". They are conscious of the fact that the boys rule over large spaces and that they "get rid of" girls from said spaces. They are of the opinion that teachers ought to intervene in order to prevent these situations:

"The boys are in charge in large spaces and the girls in charge with in small ones, but the boys get rid of girls in different spaces, and it is the teachers' job to address this, and we have not discussed this in the classroom, nor do we know how to begin to address it." (Girl, Primary, GD15/ 2009/09/23)

They reflect upon the importance wh ich certain games and toys hold for learning about gender roles. They are of the opinion that girls spend more time in the 'house corner' and play more with dolls, it prepares them to assume the roles socially assigned to them:

"The girls tend to play the role of housewife" (Girl/ Infant/ GD 11/2009/09/22)

"Dolls orient children towards care and towards the domestic field, balls orient them towards developing physical abilities, being in a group and appropriating space" (Boy/ P.E. / GD9/2009/09/21)

Along this line of thinking, [13] states that games and toys for girls are oriented towards the care of the young and, in many cases, this is taken on from a young age, as well as the responsibility of some house chores, whereas the same does not occur with boys. The implications and interventions the teachers are responsible are uniquely necessary in order to break this pattern and replace it with an adequate formation and sensitivity surrounding issues of gender. This task corresponds precisely to the Faculties of Education involved in teacher train ing. Another scarcity they mention is the lack of resources in place to work with families. They state that despite the fact that within the school the rule is each girl or boy can choose whatever toy she or he wants to play with, in some families this is not seen as appropriate and they prefer boys to play with balls or "boy's toys".

"What I see is that, within society, a small boy, for example, plays with trucks, and I see them when they bring a motorbike, a tractor or a car, yet he is not happy because he can't do what he wants. I think that pattern is enforced by society more than from the school." (Girl/ Infant/ GD1 1/2009/09/22)

"I've seen this more on the part of families rather than teacher. I've seen this with some boys... one liked very much to play with dolls and at school he played with dolls, but his father did not at all like that his son played with dolls. Immediately he would give him a ball to play with and take him to the park, but the boy wanted dolls." (Girl/ Infant/ GD 13/ 2009/09/22)

According to the statements of the student body, parents buy their children toys which propagate gender roles. They remark that, nowadays, it is still strange to see boys with a doll and buggy on the street. As stated by[1], family, education and society follow the direction of fixing gender stereotypes. Boys' toys enable masculine interests: cars and competitive, aggres sive superheroes. Girls, on the other hand, surround themselves with dolls which represent people or animals which must be taken care of, or toys related to the private sphere (ironing, make-up, kitchen...).

Stereotypes also influence choices of study or profession, since there are still many male and female young adults within Secondary or Higher Education which follow traditional gender roles when it comes to picking subjects, since they answer to what society expects from each person. However, the student body does not concede that the fact of being male or female might limit one's decision to choose certain professional or academic paths. They are of the opinion that it is something which has been overcome, and that within these issues equality has been reached. Due to this, many students are not conscious of the influence stereotypes hold over their decision.

"I don't think that people are held back by the fact of being female if they want to do Physical Education. I don't think that in this day and age there are people like that. I think that we have obtained equality. Back in the day people used to think that way, 50 years ago: man in the gym and woman at home. In Primary Education, as well as in society, we have reached a situation of equality." (Boy/ P.E. /GD2/ 2009/05/17)

When this is sue is re ferred to, part of the student body is of the opinion that choices are made due to individual tastes, in response to those who defend that often stereotypes are unseen because there is no sensitivity towards them. In any case, they think that it is a subject that should be analysed in depth.

"We don't see (stereotypes) because we're not sensitive towards them, we have yet to develop that sense. It is clear that there are more girls studying Infant Education and more boys studying Physical Education, but why is that? Are these stereotypes? Are these tastes? Does society influence people's tastes? Are there stereotypes in other careers? We have not reflected upon this, nor has it been mentioned in the classroom". (Girl/ Primary /GD15/ 2009 /09/23)

We are in agreement with[11] as regards professional choices when she states that, in the learning about gender which occurs throughout schooling, girls learn that they are more valuable within the private rather than public sphere, and that the qualities which they hold as women develop in relation to others; which then conditions their academic and professional choices. In the same manner,[9] highlights that 
there still persist several stereotyped ideas influencing over professional choices, and that it is necessary to know the latter and make them visible. Only in this way will we allow for the student body to make choices without falling into sexist sects. Certain realms, such as those associated with social attention, health or education, continue to hold a female majority. Deepening these ideas, some students say that when it comes to choosing subjects, gender roles hold a great influence. In this manner, girls choose degrees associated with the care of others, whereas boys are more likely to choose more technical paths of study, propagating the idea that teaching is "woman's job".

"...it's the same old story, girls study education, nursing or something like that, and boys engineering." (Boy/ Infant /GD1/ 2009/09/22)

"As regards equality, this school is the proof that there is no equality. In education there are much fewer men than in other degrees, for example in engineering there are many more men". (Girl/ Primary /GD7/ 2009/09/21)

"I think that now we can study whatever we want, but obviously, when we incorporate ourselves to the world of work, women don't have access to the same opportunities as men. We are very much prejudiced against by employers. Recently, we have started to see women in high management positions, but it still isn't very normal". (Girl/ Primary /GD7/ 2009/09/21)

Within the subject options of an education degree there also exist hierarchies. The data regarding the number of males and females in the different subjects within the degree, as aforementioned, do not leave room for doubt and this will imply the feminisation of infant schools will persist in the following years, contrary to the lack of wo men teaching P.E. This is reflected in their statements:

"Women have always looked after us, the mother or the girl and the profession of Infant Education is for women, and Physical Education on the other hand... seems to be for the male teacher. (Girl/Infant / GD 13/ 2009/09/22)

"Rather than equality it seems that in Infant Education there aren't men who can be teachers, it remains a profession for women". (Girl/ Infant /GD13/ 2009/09/22)

"There is only one boy in our class, ha-ha..." (Girl/ Infant /GD11/ 2009/09/22)

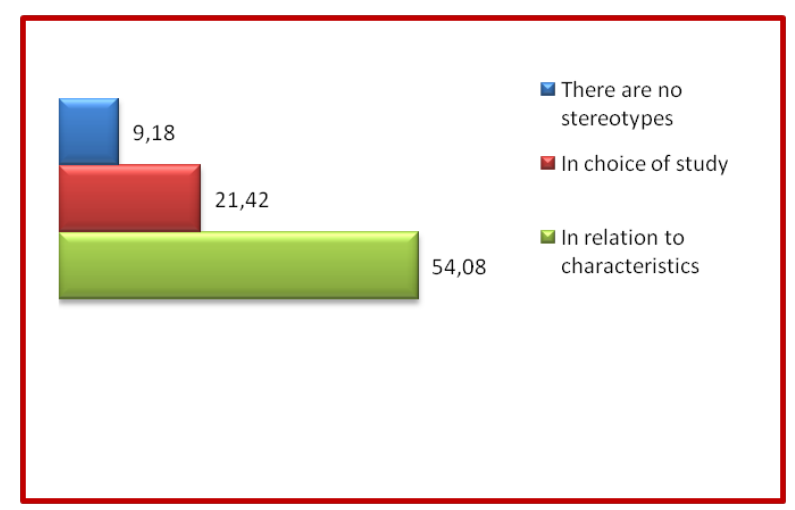

Figure 3. present stereotypes in the Education Faculty
In figure 3, we can see how many references occur in the discussion groups with the student body in relation to the existence or lack thereof of stereotypes, to do with physical characteristics and with choices of study

It is interesting to see how within the discussion groups within Physical Education, more importance is given to stereotypes, justifying them with physical capacity. Whereas within Infant Education, it is commented that the fact of being a wo man has mediated their choice of specialisation, more than occurs in other specialisations, as can be seen in Table 1:

Table 1. Percentage of mentions within these categories, organised by subject

\begin{tabular}{|c|c|c|c|}
\hline & $\begin{array}{c}\text { A : Choice } \\
\text { of study }\end{array}$ & $\begin{array}{c}\text { B : Regarding } \\
\text { characteristics }\end{array}$ & $\begin{array}{c}\text { C : There are } \\
\text { no stereotypes }\end{array}$ \\
\hline $\begin{array}{c}1: \text { Infant } \\
\text { Education }\end{array}$ & $32,61 \%$ & $34,23 \%$ & $32,74 \%$ \\
\hline $\begin{array}{c}2: \text { Physical } \\
\text { Education }\end{array}$ & $48,16 \%$ & $44,38 \%$ & $49,24 \%$ \\
\hline $\begin{array}{c}3: \text { Primary } \\
\text { Education }\end{array}$ & $19,22 \%$ & $21,4 \%$ & $18,02 \%$ \\
\hline
\end{tabular}

We can see that within the specialisation of Physical Education, they state more frequently that there are no stereotypes, and that it is the specialisation where physical ability as relates to gender is paid the greatest importance, unlike what occurs with in Primary Education.

\section{Conclusions}

Despite the discourse of equality which surrounds us, we are immersed in a patriarchal society where androcentricity invades all realms. In that which concerns us, it is clear that androcentricity is anchored within the institution of the school. It invades language through which we commun icate, through which we interpret the world, it is present in the material we utilise which ignores half the population, wo men; it is present in the play areas where girls and boys share a great part of their time and in relations of dominance / subordination / dependency which is established between them.

We find them even in the patterns of relation with in the very student body of the university which reflect the communication styles of dependency/dominance and which they themselves confess to be the case (us girls are quieter, boys get involved more, they're louder, they seek attention).

It is present in the schooling organisation, which makes wo men settle in the lower levels of the educational system and we will continue to witness the tendencies of the latest matriculations, where particularly in Infant Education (0-6 years) practically $100 \%$ of students are wo men. We willneed to ask ourselves why, after almost two centuries, this continues to be the same, and ask what occurs with the view of certain professional and academic choices seen as 
"appropriate" for each gender. In this manner we can conclude this article stating:

Despite the discourse of equality which surrounds us, we are immersed in a patriarchal society where androcentricity invades all realms. In that which concerns us, it is clear that androcentricity is anchored within the institution of the school. It invades language through which we communicate, through which we interpret the world, it is present in the material we utilise which ignores half the population, wo men; it is present in the play areas where girls and boys share a great part of their time and in relations of dominance / subordination/dependency which is established between them.

We find them even in the patterns of relation with in the very student body of the university which reflect the communication styles of dependency/dominance and which they themselves confess to be the case (us girls are quieter, boys get involved more, they're louder, they seek attention)...

It is present in the schooling organisation, which makes wo men settle in the lower levels of the educational system and we will continue to witness the tendencies of the latest matriculations, where particularly in Infant Education (0-6 years ) practically $100 \%$ of students are wo men. We willneed to ask ourselves why, after almost two centuries, this continues to be the same, and ask what occurs with the view of certain professional and academic choices seen as "appropriate" for each gender. In this manner we can conclude this article stating:

1. In general, people who study in the Faculty of Education at the University of Vitoria do not see stereotypes for what they are, unless this subject is specifically targeted and elaborated upon. A lack has been thus detected, in the present study programmes of this centre, and a necessity for formation and heightened sensitivity has been recognised.

2. Just as it occurs in other investigations, certain behaviours and characteristics seen as gender-appropriate are attributed to each sex, attributing to the masculine all that is related with strength, power, leadership... and to the femin ine, sweetness, softness sensitivity and care.

3. Stereotyped beliefs which hold certain behaviours belong to one sex and others to the other provoke the fact that, if we don't establish a concrete effort towards a heightened sensitivity and education regarding gender during the initial stages of teacher training, our future teachers will understand it as natural that girls and boys hold differentiated characteristics, and thus they will continue to transfer the values of patriarchal society within schools.

4. The choice of subjects of study seems conditioned by gender stereotypes. In this manner, girls choose to specialise in Infant Education since it is associated with care and the private sphere, whereas boys choose Physical Education, because it is associated with physical aptitude and movement. Yet, whereas in Physical Education there has been a rise in the female participation, the same does not occur with males and Infant Education.
Having gathered these conclusions with a view to the future of teacher training, we believe that there are various lessons to be learnt, since it is necessary to improve the professional orientation in order to face the problem of stereotyped decisions, with a greater conscientiousness regarding the great influence which gender stereotypes hold; and with better tools for this purpose[7].

Within the initial stages of teacher training, it is necessary and urgent to include content which helps us visualise those discriminations which, today, we may be subject to. In other words, we must "train the eye" for this to be possible. In light of the contributions gathered in the discussion groups, we think that the practical research groups can be an invaluable observatory in order to heighten consciousness regarding these issues. There are numerous guides and manuals which can facilitate this task. It is the job and responsibility of the University Educational Faculties to put these tools in the hands of our student and teaching body.

Despite the fact that we are conscious that the school, on its own, cannot change society's values, we are also conscious that virtually $100 \%$ of the population experiences schooling of some form and within her our future teachers and governing bodies are formed. In this manner,[13] tells us that "The educational system cannot, on its own, eliminate the differences contained within society, but the change must occur at some point or moment... and education is an ess ential step towards said change" We are convinced that by offering an adequate education and the necessary tools for intervention to new teachers, we can influence the advancement towards a more egalitarian society. We believe that it is time to break th is chain and for th is purpose, it is a necessary task to detach from the importance given to stereotypes as configurating factors of reality; in order to delegitimize patriarchal power based on prejudice and privilege[12].

Within Faculties of Education we hold the social responsibility of embarking these issues with the end of supplying future teachers with the tools to face the discriminatory situations produced in schools both within and outside the classroom. We're onto this!

\section{REFERENCES}

[1] Arenas, M. G. (2006). Triunfantes perdedoras: investigación sobre la vida de las niñas en la escuela. Barcelona: Graó.

[2] Ballarín, P., Lomas, C., Simón, E., Solsona, N., \& Tomé, A. (2007). Guía de buenas prácticas para favorecer la igualdad de hombres y mujeres en educación. Sevilla: Consejería de Educación de la Junta de Andalucía.

[3] Bengoechea, M. (2005). Modelos comunicativos y de relación. In SARE Nazioarteko Kongresua: Egungo neskak, etorkizuneko emakumeak. Donostia: Emakunde.

[4] Carbonell, J. (1996). Educación sexista y coeducación. La escuela entre la utopía y la realidad. Diez temas de sociología de la edu cación. Barcelona: Octaedro. 
[5] Carrasco Macías, M. J. (2007). La dirección escolar desde la perpectiva de género. In M. G. Arenas (ed.) Pensando la educación desde las mujeres, (pp. 71-90). Málaga: Atenea.

[6] Espinosa Bayal, M. A. (2005). Generoa eta ereduak familian. In SARE. Nazioarteko Kongresua: Egungo neskak, etorkizuneko emakumeak (pp. 31-40). Donostia: Emakunde.

[7] European Comision. (2009). Report on equality between women and men 2010 doi: 10.2767/86519

[8] Francis, B. (2005). Las niñas en el aula. Nuevas investigaciones, viejas desigualdades identidad de género en el marco escolar In SARE Congreso Internacional: Niñas son, mujeres serán (pp. 55-67). Donostia: Emakunde.

[9] González Lopez, I. (2009). La orientación académica y profesional en clave de igualdad. Participación Educativa, 11, $110-121$

[10] Red2Red Consultores. (2004). La situación actual de la educación para la igualdad en España. Madrid: Instituto de la Mujer.

[11] Sánchez Bello, A. (2002). El androcentrismo científico: el obstáculo para la igualdad de género en la escuela actual. Educar, 29, 91-102.
[12] Sanchez Bello, A. \& Iglesias Galdo, A. (2008). Curriculum oculto en el aula: estereotipos en acción. In R. Cobo (ed.). Educar en la ciudadanía. Perspectivas feministas (pp. 123-150). Madrid: Los libros de la Catarata.

[13] Subirats, M. (2007). De la escuela mixta a la coeducación. La educación de las niñas: El aprendizaje de la subordinación. In A. Vega Navarro (coord.). Mujer y educación. Una perspectiva de género (pp. 137-148). Málaga: Aljibe.

[14] Taberner Guasp, J. (2009). Soziologia eta hezkuntza: Hezkuntza-sistema gizarte modernoetan funtzioak, aldaketak eta gatazkak. Bilbo: UPV/EHU.

[15] Tomé Gonzalez, A. (2007). Las relaciones de género en la adolescencia. In A. Vega Navarro (coord.). Mujer y educación: Una perspectiva de género (pp. 116-136). Málaga: Aljibe.

[16] Vizcarra, M.T.; Macazaga, L. \& Rekalde, I. (2009). Eskolako kirol lehiaketan neskek dituzten baloreak eta beharrak. Bilbao: Emakunde.

[17] Yzerbyt, V. \& Schadron, G. (1996). Estereotipos y juicio social. In R. Y. Bourhis \& J. P. Leyens (Eds.). Estereotipos, discriminación y relaciones entre grupos (pp. 113-137). Madrid: McGraw-Hill. 